\title{
The Fountain of Apollonia in Illyria, A Comparative Study
}

\author{
Loreta Çapeli \\ Polytechnic University. Faculty of Architecture and Urbanism, Rruga “M. Gjollesha”, 54, Tirana, Albania
}

\begin{abstract}
The fountain - houses were important structures in the Greek cities. This article proposes the typological study of the Apollonia's fountain, in order to understand if it had a particular shape, like the researchers often say, or has been influenced and similar to any other fountain. This objective was achieved through the chronological and comparative study of well known examples of Greek fountains, highlighting their altimetry and plan composition shape. The study, conclude that Apollonia's fountain shows clear compositional similarities to a few of the $4^{\text {th }}-3^{\text {rd }}$ Century B.C. Greek fountains, and it was among the most sophisticated types in the evolution time.
\end{abstract}

Keywords: Water, Fountain, Apollonia, Illyria.

\section{Introduction}

Since its discovery in 1960, different researchers named it, in turn, a Fountain or a Nymphaeum. Praschniker, indicated its location for the first time in 1918 [1] while Straboni, cited by Ceka, will convey that in the Apollinate region there is a place named Nymphaeum "where fire comes out of the rock and mild water and asphalt regurgitates beneath it". Cabannes after a formal description, names it a nymphaion of the $4^{\text {th }}$ Century B.C., [3] as well as at the same time at the Archeological Map of Albania [4] we will find its description again as a Nymphaeum, but chronologically dated by the authors in the middle of the $3^{\text {rd }}$ Century B.C.. They qualify it as the biggest monument of Apollonia, spread over the hill slope over an area of $1,500 \mathrm{~m}^{2}$. On the upper parts of the hill, a network of horizontal conduits and perpendicular collectors convey the spring water, together with the seasonal rain water, to a central water deposit situated at the foot of the hill. (Figure 1)

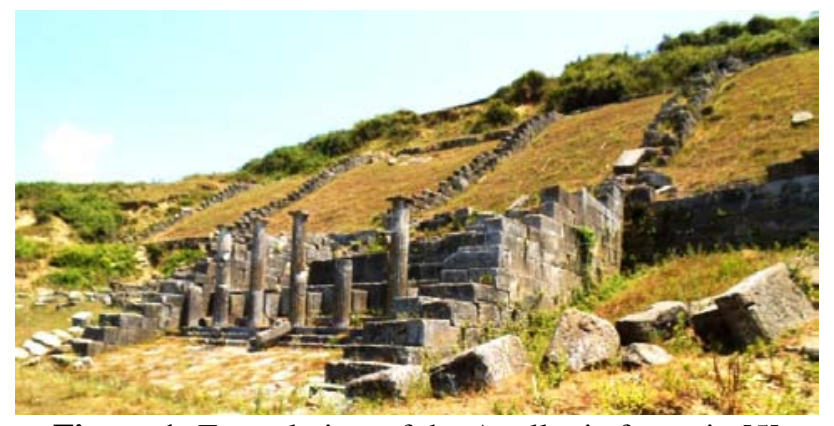

Figure 1: Frontal view of the Apollonia fountain [5]

The water deposit is part of the monumental structure of the fountain. Its plan is of prismatic shape and divided into two basins - the upper first basin served for the decantation of the water impurities, while the second basin, with regular rectangular shape, stored the purified water ready to be drawn by the citizens. (figure 2)

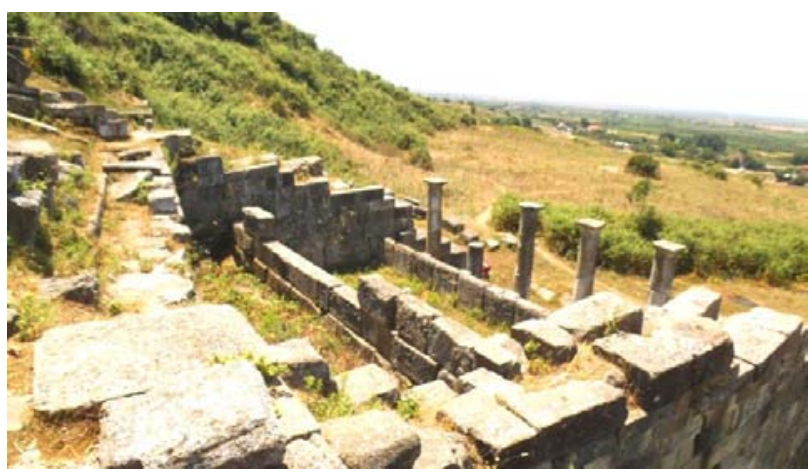

Figure 2: Bird 'e s eye view of the fountain at the lower collector level. [5] Note the basins shape and the water stone channel into the lateral masonry wall.

A Doric colonnade 2,95m high upfront with 5 or 6 columns will constitute the main façade of the fountain. We mentioned an uncertain number of columns either 5 or 6 , because we have noticed a contradiction in the hypothetical reconstruction of the fountain front colonnade as described at the "Historia e arkitekturës Shqiptare" (History of Albanian Architecture) [6] with 6 columns versus the actual situation with 5 ones after the anastylosis of the ' 74 "s. We must recall here the aesthetic rules of ancient Greece in matter of frontal colonnades where the number of them must always be a pair one - a common rule applied in the building typologies of temples, where the symmetrical axis becomes an access route. The front having 5 columns make the axis fall onto a column and not in between of them but, considering that at the fountain the full front of the water basin would have to be accessed and not only the central part of it, this anomaly could have been tolerated. It remains to be seen if similar solutions are present in other fountains or this is peculiar to the Apollonia Fountain. In the meantime for the same building we found a nominative as „Fountain of the Apollonia"e at "History of Albanian Architecture". The authors identify the building as a structure of the 4th Century B.C.. Considering a partial reconstruction (anastylosis) completed previously in the frontal part of the building, they will do an accurate description of the shape and of its function that it should have had at the time of construction. In the north-west side of the acropolis, the presence of natural 


\section{International Journal of Science and Research (IJSR) \\ ISSN (Online): 2319-7064}

Index Copernicus Value (2013): 6.14 | Impact Factor (2014): 5.611

spring water and the potential of additional rain water collectable from the hills slope should have been the incentive to complete the construction of an imposing hydraulic network of ducts and of a building of fine architecture [6]. The network which collects the rain fall and the spring water is composed by an upper, horizontal, covered conduit $70 \mathrm{~m}$ long, made with stone wall $1.6 \mathrm{~m}$ high, which conveyed the water towards five reclined step-like stone conduits, also covered, down to a second lower level collector ( $-17 \mathrm{~m}$ below) and then all the water was conveyed to the first basin for decantation. (Figure 3, 4)

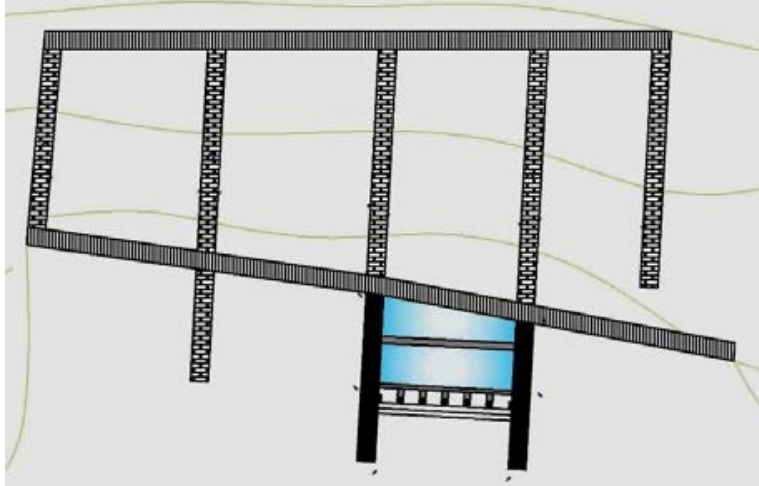

Figure 3: Apollonia Fountain plan. [5]. Note the water conduits network

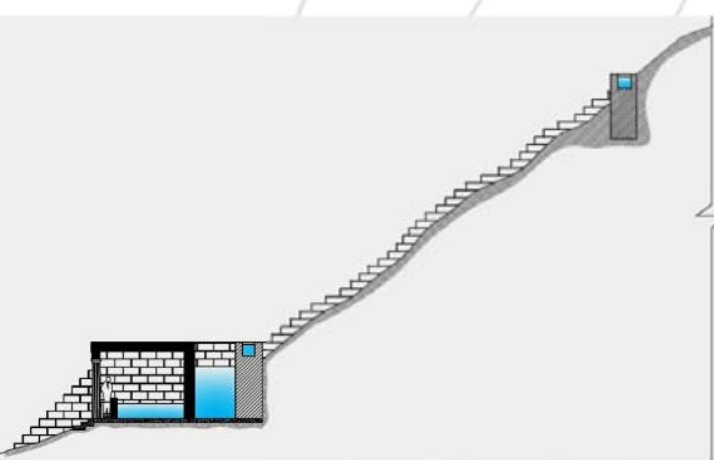

Figure 4: Technical section at the Apollonia Fountain and the hill behind.[5] Note the open "V" shape of frontal basement stone

The lower collector was built attached to the massive retaining wall which keeps off the hill grounds from sliding down. The water basin was built with regularly shaped blocks of stone. The façade is a Doric colonnade over a stylobate. The basin itself is composed by two parts - one for the purpose of storage and decantation of the water and the second for its drawing by the people. The lower water collector has outlets for the occasions when excess rain water had to be expelled out of the main basin because of abundant rain. The excess water was poured through side stone conduits and then in front of the fountain portico and further on to the lower parts of the hill. The stone pavement in front of the fountain colonnade was made as an open "V" shape stone slopes in order to facilitate the purge of excessive water but in the same time keeping the front accessible at all times. So described, we can imagine that this structure was built for the sole purpose of the collection, treatment and storage of drinking fresh water, through the use of the principles of hydraulics of the fluids, and their purification processes.

\section{Materials and methods}

In the ancient Greece the fountains were necessary structures, given the low rain precipitation in the region. They were built to manage the scarcity and the irregularity of the water supply and to make drinking water accessible to the population of the cities. [7] The position of the fountains relative to the urban level differs - when the water source level happened to be beneath the urban level, the basins were accessible through stairs; when the water source level was almost at the same level to the urban one, the fountains were composed by one single basin that collected the water; while when the water source was uphill - in a position too difficult to be accessed by people - then conduits and pipes were built to convey the spring water to the basins below. These basins were sometimes uncovered but, in order to protect the water basin from evaporation, dust, leaves and other impurities, they were roofed with timber structures that stood over stone walls and colonnade architraves. [8]The initial information comes from paintings on ceramic vases that represent young girls filling their hydra with water, in simple structures that have only sculpted lion - head stone spouts with open mouths for water pouring. [8] (Figure 5).
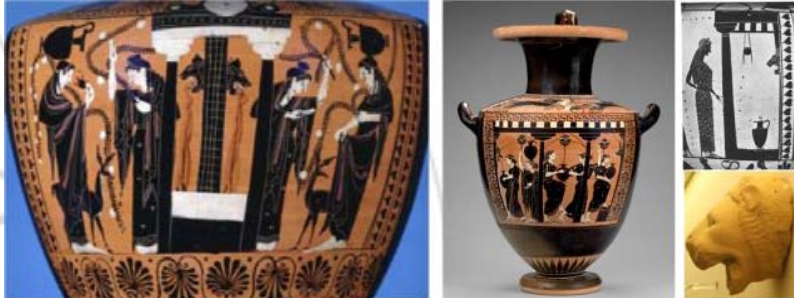

Figure 5: Ceramic vase[9] and hydra[10] designed with fountains motives. The last right photo show a lion-head spout conserved in the Apollonia archeological museum. [5]
Looking at these images we can note that the fountains they represent should have been during their initial evolution phase. This is a conclusion that we get by looking carefully at the image of the Doric capital which has at the echini, a curved form like the archaic capital of the $7^{\text {th }}$ and $6^{\text {th }}$ Century B.C.. Other archaic fountains may have been of the Tholos type that served as wells for the water that was found deeper underground.

The increasing living standards of the population commonly require a technical solution to the problem of non-uniformity of the water supply - especially during the summer season. This problem was solved by the transformation of the fountains that used only running spring water sources, in fountains equipped with basins or cisterns for long - term water storage, roofed and built with consistent supporting walls and frontal colonnades. This evolution will occur, chronologically, very fast and till the $7^{\text {th }}$ Century B.C. all technical and functional problems associated with these structures will be solved definitively. [8] From the years 600 B.C. and beyond, we will see different types of fountains that, initially, up to the year 350 B.C. will follow the same functional schemes and then, later, will be refined and enriched with a set of architectonic elements that will change its style and shape. Dunkley tells us that, even though being built at the same chronological time, it happens that the 


\section{International Journal of Science and Research (IJSR) \\ ISSN (Online): 2319-7064 \\ Index Copernicus Value (2013): 6.14 | Impact Factor (2014): 5.611}

shapes of the fountains could differ because, once the typological evolution is complete and all technical issues solved, the structures would be affected by elements like the spring position, the natural terrain where it was built on, or the construction materials available on site and their best use.

In order to fully comprehend the shape of Apollonia fountain it was necessary to study the entire evolution of the typology along centuries and then, point out the similarities found between other fountains built prior, or at the time, of its construction. Since the beginning of the first millennium B.C. some water sources were well known: the water source of Perseia in Mycenae (Figure 6), the cave water source of the Acropolis in Athens and the spring identified as Kallirrhoe in the South - East part of the Agora of Athens, that had simple structures built nearby the water source, so to help people access the fresh water of the spring.

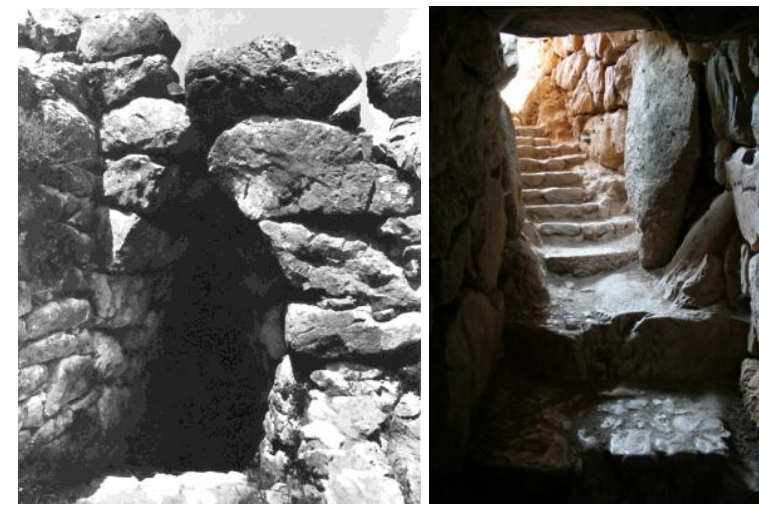

Figure 6: Source of Perseia in Mycenae [11]

Between the $7^{\text {th }}$ and $6^{\text {th }}$ Century B.C., Megara ${ }^{\text {es }}$ Fountain was built. It had two cisterns or basins to collect and store the water and should have been covered by a flat roof of stone slabs - given that the rows of regular columns found inside the basins, by no other means, would have served to support the heavy weight of the cover. (Figure 7,a),

In the same bracket of time - built at the end of the $7^{\text {th }}$ Century B.C - in Corinth, we can see the Glauke Fountain (Figure 7,b) which was supplied by water from a rather distant location that was conveyed to the fountain through a long curved conduit. Notice here that we have a similar composition with that of Megara fountain with the difference that the narrow and long cisterns do not need the use of columns to support its roof cover. The columns of the portico simply played a nice architectonic rhythmic role in the façade.
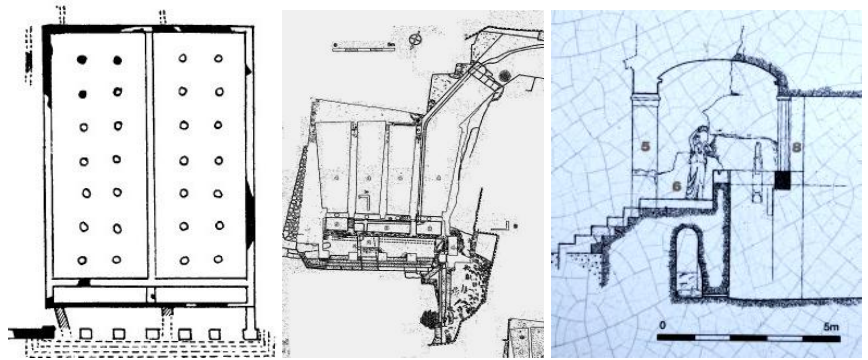

Figure 7: a)Megara Fountain, plan [8], b)Glauke fountain, plan and section [12]
Another contemporary fountain - Pirene of Corinth - as by the plan drafted by Foeler [8] (Figure 8,a), has four longitudinal cisterns that collected the water coming out from the clay layers of the hill. Carved out of the rock, they used it also as a cover. The resulting water was then conveyed at three basins and made accessible to people. The façade should have been equipped with pillars or rock supports to allow for the people to stand in front of the fountain and to draw water from it. From Dunkley we get the opinion that this building construction should correspond with the time of Periander [8] at the end of the $7^{\text {th }}$ Century B.C., some time before the construction of the Apollonia Fountain.

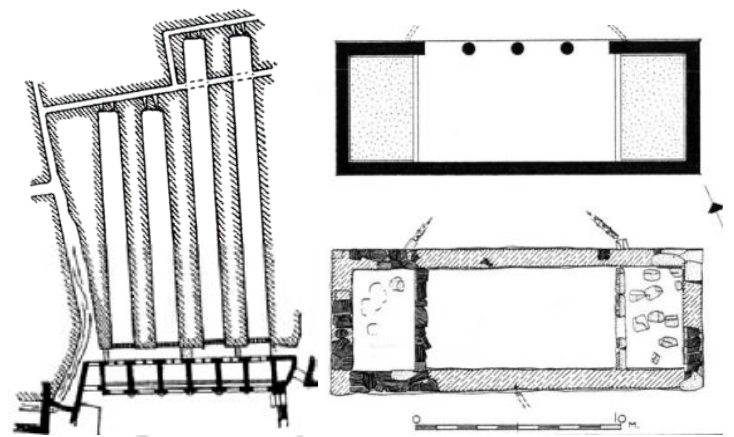

Figure 8: a)Pierene fountain plan,[8] b) Enneakrounos fountain plan [13]

Not far from Corinth, at the south-east of Athinaes Agora, is the "Enneakrounos" fountain (Figure 8,b), that dates back in the middle of the $6^{\text {th }}$ Century B.C. and that used the water of a natural spring - Kallirhoe [13]. It had two symmetrical basins on both sides of a covered space preceded by a portico with three columns where people entered to draw water while being under cover. The ceramic conduits that supplied it with water were built under the fountain. We see, again, the use of simple rectangular shaped basins and porticos with Doric colonnades as their façades. The building was covered by a two slopes pitched roof built with a timber structure. Meanwhile another fountain in Corinth Agora (Figure 8,a) that is thought to be of the end of the $6^{\text {th }}$ Century B.C., was built in a cave where the water sprung out well before its construction. The cave interior was put in order on three sides by stone walls leaving open the front side for access. The water spring outlets were equipped with metallic lion head spouts that let the water pass through their open mouths. Notice that a similar spout made out of stone can be seen at the Apollonia"s Archeological Museum (ref. figure 5). A different compositional shape, named sunken-basin type fountain, [14] is shown by the Terrace Fountain at the Temple of Delphi which dates back in the middle of 6th Century B.C. This fountain had an underground basin, similar to the fountain in Delos (Figure 9) of the middle of 5th Century B.C.. In Delos, the rectangular basin was surrounded by a building that opened up with columns on one side and the people were able to access the water basin only through steps downward. 


\section{International Journal of Science and Research (IJSR) \\ ISSN (Online): 2319-7064}

Index Copernicus Value (2013): 6.14 | Impact Factor (2014): 5.611

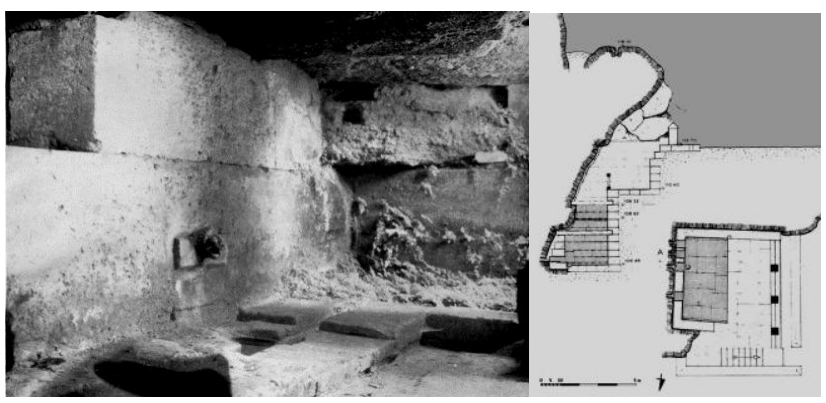

Figure 8: a) Fountain in Corinth Agora [8], b) Klepsydra fountain, plan and section [15]
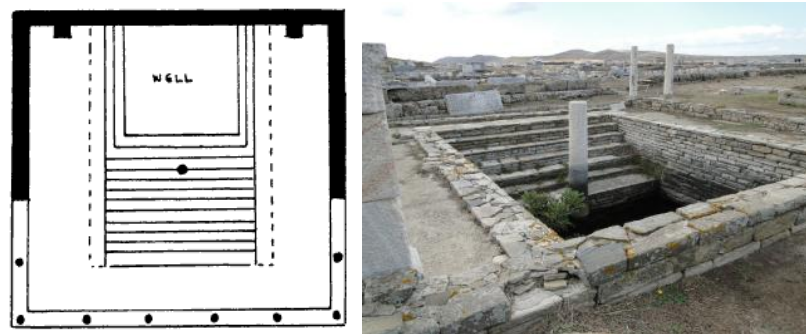

Figure 9: Plan [8] and view [16] of Delos fountain.

In the same century the Klepsydra Fountain (Figure 8,b) in Athens Acropolis, built around the years 470 to 460 B.C. have again, on the side of the portico that serves as a building façade, some steps which lead down to the water basin that is 5 meters below the ground level. The fountain of Akgros in Sicily, (Figure 10) dated in the end of the $5^{\text {th }}$ Century B.C., have two basins positioned in a longitudinal way beside the rock, connected to each other but distanced from the cliff.
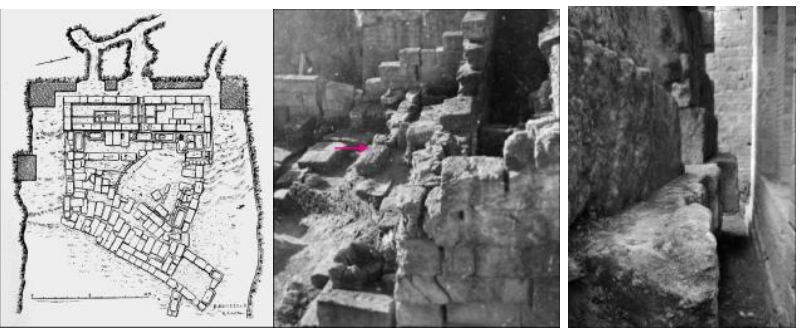

Figure 10: Akragas fountain plan view [17], Note at the last photo the basin,s posterior wall wich leans from the cliff

From that fact, it can be deduced may be the Apollonia basin should have been too, distanced from the hill through that wall, wich so far is called separation wall. On the isodomic masonry walls we can spot rectangular holes opened in the stone that probably were used to plug in the ceramic ducts that supplied the basin with water.[17] The water could be drawn out at three openings with the shape of windows on the façade from the square side that was preceded by a portico with rectangular pillars, added probably, on the $4^{\text {th }}$ or $3^{\text {rd }}$ Century B.C. It is interesting to notice the treatment of water by decantation in basins similar to the fountain of Delphi, which tells us that this method should have been a common technique used in the treatment of water. It is interesting to explore and dig deeper down at the Fountain of Apollonia to see if there are also decantation basins there. During the $4^{\text {th }}$ Century B.C, some morphological novelties arise. The SW Fountain of the Athens Agora shows an unusual composition for its time. [13] An „L" shaped plan was the result of the narrow site where it was built and should have been the best economic solution for the covering of a rather big area of basins (Figure 11).

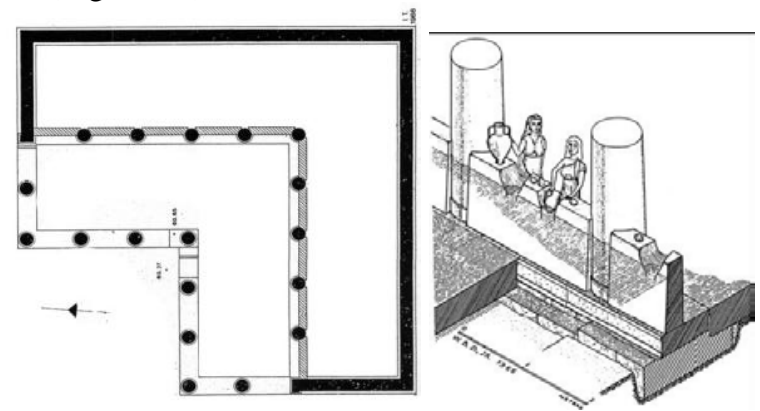

Figure 11: The SW Fountain of the Athens Agora [13]

The angular colonnade with Doric columns will become the nice architectonic façade that rose to the challenge of the required monumentality of the Agora and created the pre access area that leaded towards the angled basin. Here we find some similarities with Apollonia where the supports of the parapet stone blocks of the basin are reinforced by perpendicular blocks and attached to the columns of the colonnade. In the same century, Dipylon gate Fountain in Athens, (Figure 12,a) was built on a small surface near a city gate that probably influenced its angular shape. [8]
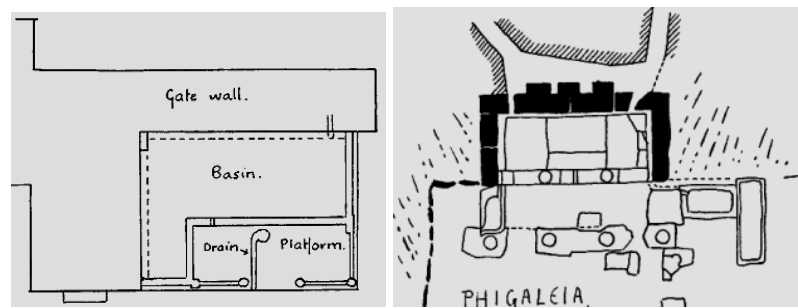

Figure 12: a)Dipylon gate Fountain plan [8], b)Phigalea fountain plan [8]

Low rise parapets between the side columns block the access and leave open only the central space to enter inside the roofed portico. Notice the asymmetric composition of the façade with the portico on one side. Sicyon gymnasia fountain (Figure 13) has a similar position to that of Apollonia. Leaned over a hill slope it had a basin limited on three sides by isodomic masonry walls and opened on the fourth side of the façade with a simple portico of two columns. (Figure 13). The filling up of the basin was done through openings in the wall decorated with stone lion - head spouts.
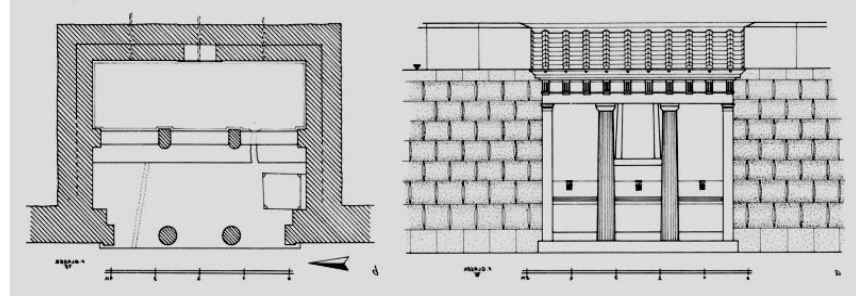

Figure 13: Sicyon gymnasia fountain plan and façade [15]

The Phigalea fountain (Figure 12,b) also shows the same shape with a basin at the hill slope similar to the Sicyon fountain. The water was be conveyed into a small basin made of isodomic masonry walls on three sides, while, on the front, the portico had 4 columns and a low parapet in between 


\section{International Journal of Science and Research (IJSR) \\ ISSN (Online): 2319-7064}

Index Copernicus Value (2013): 6.14 | Impact Factor (2014): 5.611

them. The basin was supplied by conduits on the hill slopes similar to the ones in Apollonia. It is interesting to notice that this kind of plan has been the most widespread solution that satisfied the esthetic and functional requirements of the time while being economical to build. [8] Analogically we can compare the evolution of the fountain typology to that of the Temples where the type "in antis" or prostil, had a naos anticipated by a pro-naos with columns to create an architectonic façade. In the same way, the fountains would have, minimally, a basin with columns in one side and a portico in the main façade. Clearly similar to the Apollonia fountain appears the Ialysos fountain, situated in the Rhodes Island. (Figure 14). It is composed by a basin carved in the rock and opened in its frontal part with pilasters and low blocks of stone in between them.
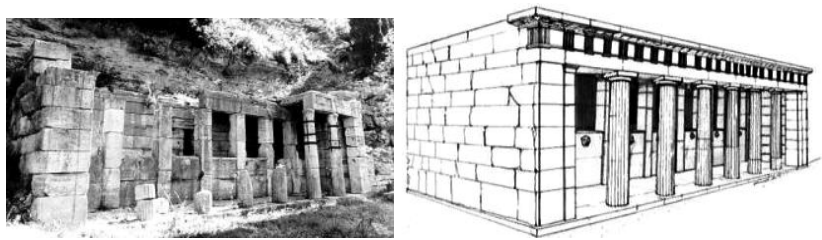

Figure 14: Ialysos fountain view [18] and hypothetical 3D image, [19]

The basin is supplied by four water spouts in the shape of the lion heads and is preceded by a portico with six Doric columns that support the roof that covers the part of the fountain where the people can draw the water. The lion head spouts were installed also in the lower parapet to facilitate the filling with water of the hydras. The $3^{\text {rd }}$ Century B.C. was a period of further shape evolution of the fountain 's typology.[8] It seems that the most successful type of the time was the one with a basin at the foot of a hill slope in order to harvest both - the rain water that falls on the hill slopes and the spring water source that would be there in the first place. A similar case of great dimensions is the Arsinoe fountain in Messene (Figure 15) that has two longitudinal basins leaned on the hill slopes in order to harvest its surface rain water. The basins were divided by a longitudinal wall and were preceded by a portico with columns. It was extended with the construction later on of two other basins on the square in front of the portico.

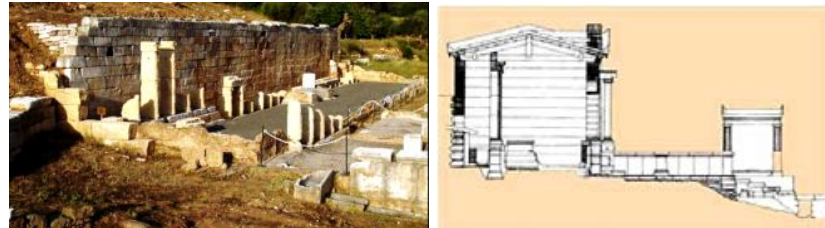

Figure 15: Arsinoe fountain view [20] and gjeometrical section [21]

\section{Results}

According to this analytic study we notice that the fountains built from the $7^{\text {th }}$ to $3^{\text {rd }}$ Century B.C. can be divided into two types:

1)Fountains having their basin under the ground level, as an underground cistern. (Klepsydra, Glauke, Delphi, Delos). In these cases steps are needed to reach the water basin in order to draw the water.
2)Fountains having the basin on the ground level - In these cases the fountain look like an ordinary building that is preceded by a low stereobat with 3 or 4 steps and needs a cover roof made of timber structure and ceramic tiles, as any other Greek building. (Megara, Dipylon gate, Enneakrounos)

Another way would be to consider the positioning of the structures. Here we notice two groups:

1)Fountains built on plain horizontal land, where all sides are visible. (Megara, Enneakrounos, Dipylon gate, SW fountain of Athene agora). The cistern, is built using isodomic masonry wall structures which are constantly under water pressure and the water flow into the basin through holes opened in its back part.

2)Fountains leaning on a hill side, that harvest also the surface rain water and only three sides of the building are visible. (sicyon, Phigalea, Ialysos, Arsenoe, Akragas). In those cases the back wall of the basin serves like a retaining wall for the hill, and there may be a network of conduits, either made out of ceramic or of stone, that harvest the water and conducts it by gravitational flow to the basin.

The common feature for all these fountains is the exterior treatment of the building - all of them, especially those from the $6^{\text {th }}$ Century B.C, were preceded by a portico with columns that defined the beautiful façade through the use of the architectonic order, which seemed to be the common solution for every kind of building and typology in the antique Greece. The Apollonia fountain is part of the second type of the fountains situated at the foot of a hill. It must be compared to other fountains pertaining to the same typology in order to establish their influence.

The comparison by type started with the fountains of Corinth and Megara, knowing that both cities were inhabited by Corinthians and that there is a fair chance that the buildings were erected by the same masters or architects originated from Corinth city. This hypothesis is reinforced by the fact that the cities are quite nearby to each other (15 km). Obviously, the fountains of Corinth and Megara, could have served as valid architectural examples for the construction of the Apollonia fountain, even considering the great geographical distance with the former two cities. Usually, in architecture, the geographical distances often contribute to stylistic and typological changes but, in the case of Apollonia, we know from a written source that Corinth continued to cultivate intensive good relations with the city and, from the middle of the $5^{\text {th }}$ Century B.C., a ground route was established between the two cities.[22] This road was built primarily for military purposes because, at the time, Corinth needed the military support of Apollonia during its wars against Athens but, naturally, it was also a road where architecture novelties and other art ideas flowed through and helped the infusion of the new trends and styles coming from the "mother" city - Corinth to the "daughter" one Apollonia. It is known that Apollonia was "polite" toward Corinth and, in return, Corinth helped it in its struggle not to fall under the Kerkira hegemony. 


\section{International Journal of Science and Research (IJSR) \\ ISSN (Online): 2319-7064}

Index Copernicus Value (2013): 6.14 | Impact Factor (2014): 5.611

It is interesting to see that Apollonia fountain has the same morphological structure to that of Megara built in $7^{\text {th }}$ Century B.C.. It has two basins - cisterns for water storage, probably covered by stone slabs on octagonal columns which were known in ancient Greece as a derivate of the quadratic columns resulting by cutting its edges off. Notice that similar columns are found in Apollonia, Bylis and Nikaia - Klos, but we do not have proof that this sort of column was used in the fountain of Apollonia. In fact, the basin is divided in two parts and we can only speculate that the internal wall could have been erected up to the level of the ceiling - similarly to the fountain in Arsinoe, helping to support the roof's weight.

It"s not deductible, from evidence found on site, either that the cover was made by a timber structure, or by a heavier stone slabs but, considering the basin's width (aprox. $6 \mathrm{~m}$ ), we may safely speculate that it was a pitched roof with timber structure covered with ceramic tiles as in a lot of other Greek buildings. But, it's irregular planimetric form, is contraindicated to be covered by a rectangular roof. So, probably the only part that could have been covered, it must have been that rectangular one, means the draw basin nearer the portico. (Refer to Figure 4) That hypothesis will be retreated subsequently.

It is interesting to see the morphological and stylistic similarities with other fountains that have been built approximately at the same time or later on than that in Apollonia. In our research we halted and looked in depth at the fountain of Arsinoe in Messene. Built in the $3^{\text {rd }}$ Century B.C., just as the fountain in Apollonia, it would be on a hill slope, harvest and collect the rain water from the hill surface to the 40 meters long decantation basin at the foot of the hill and conveying the purified water to the two front basins situated on opposite sides of the water drawing platform. We notice similarities to Apollonia regarding the longitudinal basins parallel to the façade, their longitudinal division by an internal wall, its limitation by isodomic masonry walls and the front colonnade that will support the roof and will be the façade of the whole building.

Similar morphology we can find in the fountain of Ialysos in Rhodes Island, which is distant geographically but near chronologically. Even there the basin was leaned upon the retaining wall of the hill and the water collection was done through ducts that poured water also on the side walls of the basin. Dunkley learn us that these side ducts, perpendicular to the slope of the hill, were cut in the antes of the portico and all the water was then conveyed to the basin by means of stone spacing on one row, or poured in front of the basin through lion - headed spouts. Such ducts that go downhill till they reach the porticos antes we find also in Apollonia and, if we have attention we can see the openings on the wall that have been built by distancing the stones of one row allowing for the water to outflow in periods of heavy rain. (Figure 16) It remains to be established if there have been any lion - head spouts attached to these openings as it has been the case in other similar fountains.

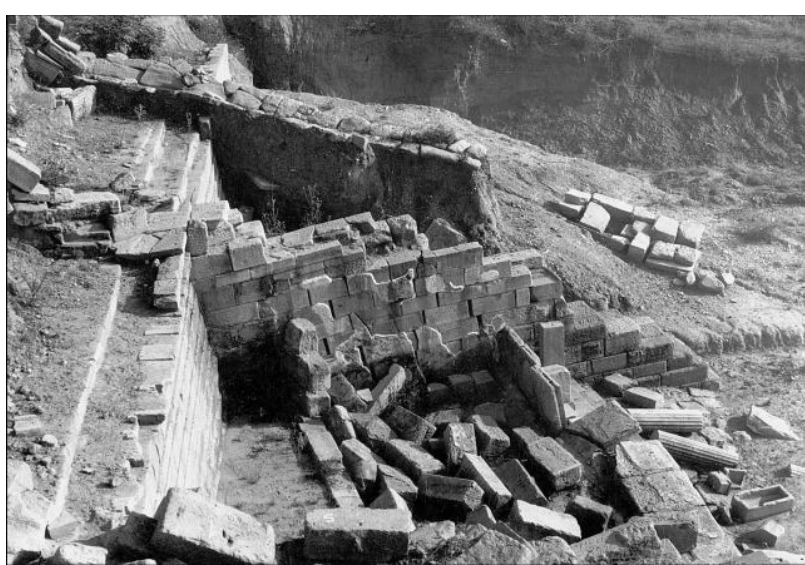

Figure 16: Aerial view of Apollonia fountain while discovered, prior the anastylosis proces of 1974. Note the open holes due the shunt of isodomics blocs on the lateral walls of the basins. [23]

Actually at the division wall of the basin in Apollonia we can spot three holes (in total should have been four) that, considering their position above the maximum water level of the draw basin, should have served as water supply spouts. (Figure 17,a) We are not able to say if the water was poured through the lion - head spouts, or where was their position, as it is the case in similar fountains. In fact, at the Apollonia Museum, there is a stone lion - head spout but it does not show any signs of metallic hooks or holes that used to fix it in place. Regarding the water basins, we hypothesize that the division wall between them was built later than the side walls because there is no structural connection between the walls, which would increase the stability of the division wall itself. The second basin (the one near the portico) should not have been fully filled with water and its water level should have been up to the height of the, previously mentioned, holes which were used as overflows of the first basin nearer to the hill.

We, also, may realize the maximum height of the water level at the first basin as being equal to the height of the overflow spouts found outside the side walls of the basin, near to the corner. (Figure 17,b)

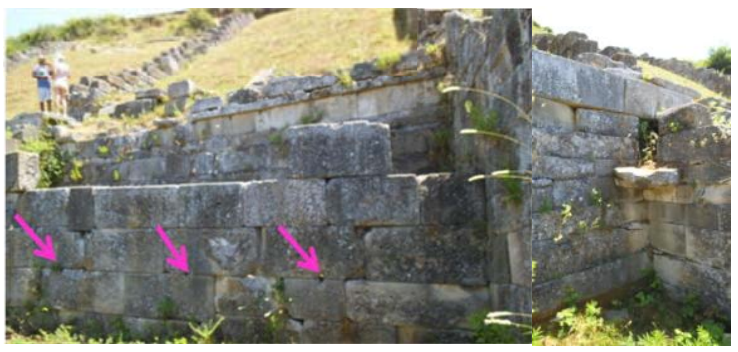

Figure 17: a) frontal view of the basin wall [5] Notice three holes which poured water into the draw basin. b) lateral overflow of the first basin.[5]

These overflow spouts poured excessive water on open ducts near the main antes wall sides. These heights, relatively low, of the water level, may explain the missing structural connection between the side walls and the basins division wall, which may not have been able to sustain the water pressure exercised upon it if it was to be filled up to its full height but, was good enough as a roof support as such. 


\section{International Journal of Science and Research (IJSR) \\ ISSN (Online): 2319-7064}

Index Copernicus Value (2013): 6.14 | Impact Factor (2014): 5.611

\section{Conclusions}

This article introduces a comparative study for similar monuments relevant to other contexts. That comparison, as well the constant references to similar fountain 's architectures, open a wider typological horizon for the understanding of the Apollonia Fountain. Comparing the Fountain at Apollonia to those at Pirene, Glauke and Megara we were able to notice their plan and façade similarities but we should be careful and point out that things are rather different in altimetry. In Apollonia's case we have an arrangement of the fountain as a water source which collects the water coming from above, while in the cases of Glauke and, Pirene, the water is collected from below and we would need to climb up a stair in order to reach to the portico.

The basins of Megara, Glauke and Pirene are preceded by a portico with 5 columns and 2 pillars of rectangular shape, similarly to the Fountain of Apollonia, thus with an odd number of columns that position a columns right in the middle, where the symmetry axis of the façade is.

Fountain physiognomy with two basins, among which the principal one distance from the hill through one other basin, resemble to the Akragas basins which distance from the cliff and don't leans on it. At Apollonia too, the posterior basin it must have been uncovered, and served to supply the rain water from the hill and the draw basin's roof too.

Apollonia Fountain resulted to be almost identical to the Ialysos Fountain in Rhodes Island with regards to its hydraulic scheme and architectonic appearance. Being a very well preserved monument and one of the best known cases of this typology, it may help explain some of the questions about the original form of Apollonia Fountain.

\section{Discussions and Recommendations}

It must point out that, in the published works of the Albanian researchers, Apollonia Fountain is often qualified as a monumental object that possesses "a special form", "unusual" and "unique in its kind" or "a special monument of the antique world". Are these researchers right on their assertions? This study tried to demonstrate that, what the Apollonians built was similar to other structures built between the $4^{\text {th }}$ and $3^{\text {nd }}$ Century B.C. pertaining to the same typology and, surely enough, it was one of the beautiful examples of its time. It is regrettable that there is no mention, of any kind, about this fountain in the specialized literature. This study will serve to increase the attention of the specialists and the people in general over this nice piece of ancient architecture. In the future, this fountain should be examined more carefully, aiming to the complete understanding of its original shape that may have been altered in error during the anastylosis carried out in 1974. The determinations of the roof shape and its cover material, or the hydraulic scheme of the system, are some of the topics that remain open for inquiry and will be treated in another study.

\section{References}

[1] Praschniker, C. (1922). Muzakhia aus Malakastra: Archäologische Untersuchungen in Mittelalbanien. JEEAI, vol.21-22, p.23-57.

[2] Ceka, N. (2005). Apollonia. Tiranë: Migjeni, 82

[3] Cabannes, P. (1/1986). Recherche archeologique en Albanie 1945-1985. Revue Archéologique, Nouvelle Série, p. 107-142.

[4] Pierres Cabanes, et al. (2008). Harta arkeologjike e Shqipërisë. Pegi, p. 99

[5] Author"s photo/ design.

[6] Apollon Baçe, et al. (1976). Historia e Arkitektures Shqiptare. Tirane: Ministria arsimit dhe kultures, p. 121

[7] Jouanna, J. (1996). Hippocrate, Airs, eaux, lieux. Les Belles Lettres, 52(52-2).

[8] Dunkley, B. (1936). Greek Fountain-Buildings before 300 B.C. The Annual of the British School at Athens, Vol. 36, 142-204.

[9] (C) The Trustees of the British Museum

[10] (C) Museum of Fine Arts, Boston

[11] [Online]. Available http://www.greece.com

[12] [Online]. Available http://www.pausaniasfootsteps.nl/english/corinth-archaeological

[13]Lang, M. (1968). Waterworks in the athenian agora. Princeton, New Jersey: American school of classical studies at Athens.

[14] Wycherley, R. E. (1962). How the Greeks Built Cities. New York: Norton \& Company.

[15] [Online]. Available http://www.hydriaproject.net

[16] [Online]. Available http://www.wikimedia.org

[17] Fino, A. (2014, 2). La fontana arcaica di San Biagio ad Agrigento. Thiasos, rivista di archeologia e architetura antica, 67-91.

[18] [Online]. Available http://www.rhodesinfo.gr.

[19] Petri S. Juuti, et al. (2015). Short global history of fountains. Water. [Online]. available http://www.mdpi.com/2073-4441/7/5/2314

[20] http://www.wikimapia.org

[21] http://www.ancientmessene.gr

[22] Beaumon, R. L. (1952). Corinth, Ambracia, Apollonia. The Journal of Hellenic Studies, Vol. 72, p.62-73.

[23] Vangjel Dimo, Philippe Lenhardt, François Quantin. (2007). Apollonia d'Illyrie, Atlas archeologique et historique. p.265

\section{Author Profile}

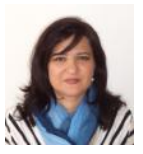

Loreta Çapeli is a lecturer of the History of Architecture at Faculty of Architecture and Urbanism of Tirana, from 1995 to date. She received a M.S degree in Architecture (1991), a Post Master degree in "Architectural Survey and Documentation Restoration of Architecture" (2006) and she is a Phd candidate in the historical study of the architectonic typologies from antiquity. Her main areas of research are the History of Architecture, both, of the World and the Albanian one, also the critics and the architectural analysis of built typologies, the re-evaluation and restoration of the monuments of cultural heritage. 